\title{
Evidence for paleo-continental margin and folding of relic fragment of the Bay of Bengal, northeast Indian subcontinent
}

Kolluru Krishna ( $\nabla$ nio.krishna@gmail.com )

University of Hyderabad

M. Ismaiel

University of Hyderabad

Abhimanyu Rajan

University of Hyderabad

Article

Keywords:

Posted Date: February 3rd, 2022

DOI: https://doi.org/10.21203/rs.3.rs-1314446/v1

License: (c) (i) This work is licensed under a Creative Commons Attribution 4.0 International License.

Read Full License 


\section{Abstract}

The processes of continental breakup and reassembling of landmasses are persistently contributing to reconfiguring the Earth's surface. In addition, deltaic sediment deposition also reshapes the face of Earth by advancing shorelines towards the ocean. Here, we show a classic example of contiguous structures of paleo-continental margin on the eastern Indian Shield and an ancient fragment of the Bay of Bengal beneath Bangladesh. In the present work, we collated gravity anomaly data from the regions of Bangladesh and adjoined parts of the Indian shield and the northern Bay of Bengal for deciphering the nature and long-term behavior of rocks. The combined gravity anomaly map illustrates nearly N-S oriented alternate bands of about $200 \mathrm{~km}$ wide positive and negative anomalies in Bangladesh region, besides showing signatures of prominent geomorphic features such as Shillong Plateau, Sylhet Trough, Burmese Arc, etc. The crustal models reveal the presence of paleo-continental margin segments on eastern edge of the Singhbhum craton and south of the Shillong Plateau, approximately $200 \mathrm{~km}$ wide folded oceanic crust beneath Bangladesh, and low gradient (about $3.0^{\circ}-3.7^{\circ}$ ) bending of the subducting Indian plate beneath the Burmese platelet. The inferred continental margin was evolved after breakup occurred between the Rajmahal-Sylhet Line and continental fragments (Elan Bank and southern parts of the Kerguelen Plateau) at about $120 \mathrm{Ma}$, and then remained in marine conditions at least until the Oligocene-Miocene time ( $23 \mathrm{Ma}$ ). Consequently, the sediments supplied by two great Himalayan rivers were excessively deposited on the margin and over an older fragment of the Bay of Bengal lithosphere for formation of Bengal Delta, leading to the delta progradation towards the ocean and creation of Bangladesh land. The oceanic crust beneath Bangladesh was folded with approximately $200 \mathrm{~km}$ wavelength as the compressive stress regime is locally operative due to the eastward moment of the Indian plate and westward propagation of the Indo-Burman Wedge.

\section{Introduction}

The passive continental margins are, in general, evolved in successive processes of rift evolution, continental breakup, and incipient sea-floor spreading. A few of these margins subsequently may modify their configuration, particularly surface morphological expressions with the deposition of huge sediments carried by the river systems and with post-breakup tectonics. The margin segments in Krishna-Godavari and Mahanadi basins on the Eastern Continental Margin of India (ECMI) are the best examples for such morphological modifications ${ }^{1-3}$. Uncommonly, massive sediment depositions may lead to extending the deltaic province, thereby advancing the shoreline towards the ocean, thus forming the sediment build continental margins that differ from margins evolved by the continental rifting and breakup process. Earlier geological and geophysical studies in onshore and offshore Bengal Basin revealed that the Bangladesh margin is built solely by the extensive progradation of deltaic deposits ${ }^{4-6}$.

As the processes of ocean floor creation and consumption continue at plate boundaries, the continental fragments at some time or other do come closer for unification, which eventually may lead to the disappearance of once existed passive continental margins, and then continue to preserve the scarps in the form of suture/ shear zones on edges of welded continental blocks. In specific geological situations, 
the segments of continental margin and large delta formation province may adjoin, leading to the burial of margin morphology. Such geological settings, although rarely exist, may through a great challenge to Earth Scientists for mapping the region and for investigating the nature and spatial extent of crustal rocks and their internal structure. The geometry of continental blocks and traces of paleo-continental margins are important constraints required for understanding their wandering through geologic time and for assembling of continental fragments, particularly for the ages of Phanerozoic Eon.

The present study area encompasses the regions of eastern Indian Shield, Bangladesh, Burmese Arc, and northern Bay of Bengal (Fig. 1), which have been evolved in different evolutionary processes and converged together because of plate tectonics and sediment depositions. The area holds key shreds of evidence for unraveling the geologic/ tectonic history of development of each geological province and their present convergence. Thick sediment strata over these provinces and inaccessibility to these regions hinder the plan of conducting trans experiments covering regions across the countries for a better understanding of the geology and dynamics of the converged area. As most investigations were carried out independently in onshore and offshore Bengal Basin regions, a comprehensive understanding was not able to make, and the nature of rocks beneath Bangladesh and northern Bay of Bengal is still debatable. The delineated continent-ocean boundary in onshore Bengal Basin suggests the presence of oceanic crust in the Bangladesh region ${ }^{7,2}$. Whereas, the velocity structure of the offshore Bengal Basin prompted Sibuet et al. ${ }^{8}$ for interpreting the presence of thinned continental crust ( $10-20 \mathrm{~km}$ thick) with insertion of volcanic material in the form of sills and seaward-dipping reflectors (SDRs).

In the present study, we collated the Bouguer gravity anomaly data of the onshore Bengal Basin covering the regions of Bangladesh and adjoining northeast Indian Shield and free-air gravity anomaly data of the offshore Bengal Basin, which is part of the northern Bay of Bengal for the purpose of generating a regional gravity map and for making observations of responses of adjoined geological entities (Figs. 1 and 2). The assembled land-sea gravity data are modeled for determining the paleo-continental margin segments attached to the Singhbhum craton and Shillong Plateau, Continent-Ocean Boundary (COB), nature and pattern of crustal rocks beneath Bangladesh, location of trench axis of the subduction zone on west of the Indo-Burman Wedge, and nature of present-day Bangladesh margin.

\section{Geological Setting Of The Northeast Indian Subcontinent And Bay Of Bengal}

The Indian Shield consists of six ancient cratonic blocks, which are stitched with younger Proterozoic mobile belts and include the basins formed during the Proterozoic Eon. A few of the volcanic provinces like Deccan, Rajmahal, and Sylhet originated from deep-mantle sources were accreted over the Precambrian rocks of Peninsular India during the Mesozoic Era. The Singhbhum craton, one of the constituents of the present research work, is bounded by the Chhotanagpur Gneissic complex and Satpura Fold belt in the north, the Eastern Ghats mobile belt and Mahanadi Rift in the south, and alluvium and Bay of Bengal in the east. The Bengal Basin, one of the thickest sedimentary basins of the world consists of more than $20 \mathrm{~km}$ thick sediments deposited during the Early Cretaceous - Late Quaternary 
period $^{9-11}$. The onshore part of the basin lies in Bangladesh and some parts of the adjoined Indian States, which is bordered by the Indian Shield to the west, the Shillong Plateau to the north, and the IndoBurman Ranges to the east (Fig. 1). While in the offshore region, the basin extends up to shelf-edge following a $200 \mathrm{~m}$ bathymetry contour. The onshore Bengal Basin is tectonically not quiescent as its eastern part experienced ocean-continent collision since the Middle Miocene ${ }^{12,13}$ and on its northward, convergence takes place across the Dauki Fault, south of the Shillong Plateau ${ }^{14,15}$.

The Indian landmass remained an integral part of the Gondwana supercontinent for a quite long period and then broke away from Antarctica-Australia about $130 \mathrm{Ma}$ ago ${ }^{16,7}$, leading to the evolution of conjugate parts of the Bay of Bengal and Enderby Basin in two phases. In the initial breakup at around $130 \mathrm{Ma}$, the Indian landmass along with the micro-continents of Elan Bank and parts of the Kerguelen Plateau separated from East Antarctica. During the second phase started around $120 \mathrm{Ma}$, a major northward ridge jump separated two micro-continents - Elan Bank and parts of the Kerguelen Plateau from the north ECMI, Singhbhum craton, and Rajmahal-Sylhet Line ${ }^{16,17,7,2}$. Later, during the Late Cretaceous, the Indian plate moved over the mantle sources, leading to the formation of two N-S oriented linear volcanic ridges $\left(85^{\circ} \mathrm{E}\right.$ and Ninetyeast ridges) in the Bay of Bengal ${ }^{18-21}$. During the Early Tertiary period, the continental collision that occurred between Indian and Eurasian plates led to the closure of the Tethys Ocean ${ }^{22}$. The collision process advanced further and headed to the rapid growth of the Himalayan orogeny, as a result, the mountain building has undergone significant erosion that eventually led to the transport of terrigenous material into the Bay of Benga| ${ }^{23,24,1}$. Thus, the eroded sediments were excessively deposited reaching more than $20 \mathrm{~km}$ in the region south of the Shillong Plateau, Bangladesh region and in Bengal Offshore Basin, northern Bay of Bengal ${ }^{25-27,1}$, from there the sediment thickness has decreased towards the equator with some sort of uniformity. The Bay of Bengal lithosphere is, in general, carpeted with two major sedimentary units deposited by different river systems ${ }^{1}$. The underneath unit was deposited with the material carried by peninsular river systems during the early Cretaceous riftstage to Oligocene-Miocene ( $23 \mathrm{Ma}$ ) Epoch. The upper unit is developed during the last $23 \mathrm{Myr}$ with the Himalayan source material carried by Ganges and Brahmaputra rivers.

It is, generally, conjectured that the lithosphere beneath Bangladesh was accreted by the seafloor spreading process, later it is completely buried under the huge thickness of alluvial sedimentary deposits brought by Ganges and Brahmaputra river systems ${ }^{4,28-30,5,6}$. The Burma platelet is surrounded by the Indian plate in the east and Sunda plate in the west and is located between the accreted volcanic ridges in the south and the Shillong Plateau crustal blocks in the north ${ }^{31}$. The platelet is structurally bounded by the active Sagaing dextral strike-slip fault in the east and the debatable Bengal Basin subduction zone in the west ${ }^{32}$. The location of the eastern margin of the Indian plate, where the Indian lithosphere subducts beneath the Burmese platelet marks a western edge of the Burmese arc region (Fig. 1). The process of ocean-continent collision led to the formation of a long arcuate fold and thrust belt, named the IndoBurma Ranges on overriding Burmese platelet. Another important feature of this study area is the Dauki 
Fault, which runs in the E-W direction on immediate south of the Shillong Plateau and has a major role in regional tectonics of the area.

\section{Collation Of Onshore And Offshore Gravity Anomaly Data}

Bangladesh and adjoined Indian Shield, and northern Bay of Bengal regions were not studied together as they belong to different physiographic domains and political territories (Fig. 1). The contiguous regions as one hold very critical and useful information for better understanding the tectonic evolution of various geological provinces and their assemblage. Otherwise, studying individual regions in isolation wouldn't provide a holistic view of the evolution of this complex region of the northeast Indian subcontinent. In order to unravel the subsurface details from this contiguous area, we collated Bouguer gravity anomaly data of Bangladesh and surrounding Indian Shield and free-air gravity anomaly data of the northern Bay of Bengal from different data sources and prepared an assimilated gravity anomaly contour map with an interval of $4 \mathrm{mGal}$ (Fig. 2). The gravity map is the first of its kind covering the land and sea domains in the region of northeast Indian subcontinent (Fig. 1). Bouguer gravity anomaly data of Bangladesh region is considered from the published Bouguer Gravity Anomaly Map of Bangladesh ${ }^{33}$. The Surrounding Indian Shield Bouguer gravity anomaly data are considered from published sources ${ }^{34-37}$ and unpublished reports of ONGC. As both Bouguer gravity anomaly data of onshore and Free-air gravity anomaly data of offshore regions present the corrected gravity data to the same reference of the datum plane, we considered both of these to prepare an assimilated gravity anomaly map for the contiguous onshore and offshore regions. Accordingly, we considered satellite (cryostat-2 and Jason-1) derived freeair gravity anomaly data of the northern Bay of Bengal ${ }^{38}$, and then combined with the Bouguer gravity anomaly data of Bangladesh and adjoining Indian Shield.

The Bouguer gravity anomaly maps of Bangladesh and adjoined Indian Shield regions were digitized using WINDIG freeware. The digital data are converted to gridded data and combined with the gridded data of free-air gravity data of the northern Bay of Bengal for preparing a combined database and to generate a combined contour map of both onshore and offshore regions (Fig. 2). Two transects running $\mathrm{E}-\mathrm{W}\left(23.4^{\circ} \mathrm{N}\right.$ latitude) and $\mathrm{N}-\mathrm{S}\left(91^{\circ} \mathrm{E}\right.$ longitude) directions covering the prominent anomaly signatures are chosen for modeling the subsurface structures. The GM-SYS software is used for determining the 2-D crustal density model for unraveling the nature of rocks within the study area (Fig. 3) and tectonic processes that the regions experienced during the past $120 \mathrm{Myr}$. The derived crustal models are more plausible as they were well constrained by the plate reconstructions models ${ }^{7}$, Seaward Dipping Reflectors ${ }^{39,40}$, magnetic doublet signatures ${ }^{41}$, Continent-Ocean Boundary line ${ }^{7,2}$, sediment thickness details $^{42,43,10}$ and depths to the Moho discontinuity ${ }^{44}$ from onshore region, and basement and Moho topographies derived from seismic reflection and gravity results of the offshore region ${ }^{1,2}$.

\section{Gravity signatures and crustal models - northeast Indian subcontinent and northern Bay of Bengal}

Bouguer gravity anomaly data of Bangladesh and surrounding Indian Shield, and Free-air gravity anomaly data of the northern Bay of Bengal are combined (Fig. 2), thereby discussing detailed gravity 
responses of the area, where different geomorphic units are adjoined. The gravity data of the study area are quite variable ranging from $-190 \mathrm{mGal}$ to $55 \mathrm{mGal}$ (Fig. 2), associates the negative value with the Himalayan Mountain Range because of deep burial of the Moho discontinuity at an average depth of 60 $80 \mathrm{~km}^{45}$ and positive value with the Bangladesh shelf-slope region because of the rise of seafloor and basement towards the coastline ${ }^{2}$. A significant $\mathrm{E}-\mathrm{W}$ elongated positive gravity anomaly reaching up to 28 $\mathrm{mGal}$ is observed accompanying more than a km elevated Shillong Plateau as the Moho discontinuity beneath it is shallower than that beneath the Sylhet Trough/ Surma Basin in the south and Brahmaputra Basin in the north $46,28,47$. The Sylhet Trough lies to the south of the Shillong Plateau, is associated with EW oriented bulged negative gravity anomaly reaching up to $-80 \mathrm{mGal}$, showing the response of $13-18 \mathrm{~km}$ thick clastic sediments deposited from the Tertiary to recent times within the trough ${ }^{4,48}$. In eastward between the coastline and Shillong Plateau, the gravity anomaly falls in W-E direction from -20 to -116 $\mathrm{mGal}$ with two different gradients having a lower one of about $30 \mathrm{mGal} / 50 \mathrm{~km}$ on deformational front and a relatively higher one of about $50 \mathrm{mGal} / 50 \mathrm{~km}$ in the vicinity of Burmese Arc (Figs. 1 and 2), representing the geometry of subducting slab of the Indian plate beneath the Burmese platelet. Towards the west, a prominent NNE-oriented narrow low gravity strip with three lower value closures within and broad positive gravity anomaly trends on either side of the strip is observed (Fig. 2). On northward around $24^{\circ} \mathrm{N}$ latitude, the low gravity strip takes a turn to NE direction and finally connects the E-W oriented Dauki thrust fault gravity anomaly. Following the geophysical observations of narrow low gravity strip, magnetic doublet ${ }^{33}$ and Seaward Dipping Reflectors $39,40,7,2$ delineated the presence of continent-ocean boundary that separates the Indian Shield from oceanic crust underlying Bangladesh. It is observed that broad positive gravity signatures lie on either side of the low gravity strip, in general, correspond to the responses of the shallow Precambrian rocks of the Indian Shield on the west and shallow Moho discontinuity on the east beneath Bangladesh. The continuity of broad positive gravity anomaly over the Indian Shield and Shillong Plateau has been notched by lower anomalies at two locations (Fig. 2), which can be interpreted as a response of paths of the Ganges and Brahmaputra river systems. The broad gravity signature over the Bangladesh region consists of near N-S oriented alternate bands of about 200 $\mathrm{km}$ wide positive and negative anomalies (Fig. 2).

Keeping the prominence of gravity signatures of the study area in view, we choose two transects in the EW direction along $23.4^{\circ} \mathrm{N}$ latitude and N-S direction along $91^{\circ} \mathrm{E}$ longitude (Fig. 2) as representative profiles for determining the crustal structure models. The $\mathrm{E}-\mathrm{W}$ transect is considered to take into account gravity signatures associated with the Indian Precambrian rocks, Bangladesh, and Burmese Arc. While the N-S transect runs through the gravity responses of the Brahmaputra Basin, Shillong Plateau, Dauki Fault, Sylhet Trough, Bangladesh, and north Bay of Bengal. For building initial crustal models, we considered details of available geological and geophysical information as detailed in the previous section. Average density values for various units of sediments, crust, and upper mantle rocks are considered from published results ${ }^{49-52}$.

The crustal models derived along both transects depict the geometry of sediment, crust, and upper mantle layers, thicknesses, and density of rocks (Fig. 3a and b). The E-W crustal model reveals the 
presence of $\sim 36 \mathrm{~km}$ thick continental crust on eastern side of the Singhbhum craton, thereupon the crust tappers off westward and adjoins 8-9 km thick oceanic rocks. On eastern side, the location of trench is marked, where the oceanic lithosphere of the Indian plate subducts with a low gradient of about $3.0^{\circ}$ to $3.7^{\circ}$ beneath the Burmese continental lithosphere (Fig. 3a). While beneath the Indo-Burma Ranges the dip of the subducting Indian plate has relatively increased to about $7.8^{\circ}-9.5^{\circ 44}$. Further east, from the IndoBurma Ranges to the Central Myanmar Basin, Zhang et al. ${ }^{53}$ imaged the slab of the Indian lithosphere being subducting at deeper depths with an increased dip angle of $\sim 25^{\circ}$. It is also observed that the oceanic crust beneath the Bangladesh region is folded in near N-S direction with a wavelength of about $200 \mathrm{~km}$ and an amplitude of about $2 \mathrm{~km}$ (Fig. 3a). The N-S crustal model shows more than $40 \mathrm{~km}$ thick continental crust beneath the Shillong Plateau with a small rise at Moho discontinuity compared to that lies beneath the oceanic crust in Sylhet Trough (Fig. 3b). Earlier studies using gravity in conjunction with seismological results ${ }^{54}$ and joint inversions of receiver functions and surface wave dispersion ${ }^{11,55}$ indicated the absence of crustal root beneath the Shillong Plateau to support the isostatic compensation. Further, the model in the vicinity of present-day shelf edge reveals more than a $\mathrm{km}$ rise at levels of the seafloor, basement, and Moho discontinuity towards the coastline. The sediments, in general, were found to be thicker beneath the Bangladesh region reaching around $20 \mathrm{~km}$ in the regions of Sylhet Trough and depressions of the folded lithosphere (Fig. $3 a$ and b). The E-W crustal model further reveals the structures of volcanic passive margin and ocean-continent collision, which were existing on surficial levels in the geological past at least up to Miocene time. Subsequently, the structures were being covered and buried under the huge thick sediments carried by the Ganges and Brahmaputra rivers from the Himalayas. The pre-Miocene structures of continental margin in the east and collision-related accretions in the west of the Bangladesh region are well comparable with the structures of present-day volcanic passive margin on the eastern margin of South America (Fig. 3 C $^{56}$ and Chilean subduction zone on the western margin of South America (Fig. 3d) ${ }^{57}$. Both volcanic margins are depicting the presence of underplated materials and SDRs with nearly similar kinds of gravity responses. Beyond the margin, the gravity anomalies are differing as those over Bangladesh are associated with the folded lithosphere. The gravity anomaly map of northeast Indian subcontinent and northern Bay of Bengal, and derived crustal structures are shown in three-dimensional view for better visualizing the correlations between the structures and gravity responses (Fig. 4). It is observed that the NNE segment of the continent-ocean boundary is solely correlated with the foot-of-the-slope of continental margin, while the NE and E-W segments of the boundary are further accompanied by the Debagram-Bogra Fault and Dauki Fault lines, respectively (Figs. 1, 2 and 4).

\section{Paleo-continental margin and relic fragment of the Bay of Bengal}

Most geological and geophysical investigations so far carried out in the present study area were in isolation, which lead to restrain understanding of evolution of all geological features in a holistic view. In order to overcome this, we combined gravity anomaly data of both land and sea regions and then modeled with tight constraints for the purpose of delineating the nature of rocks and their evolutionary history. The crustal models determined along the E-W and N-S transects (Figs. 3 and 4) vividly show the 
presence of continental margin structure on east of the Singhbhum craton and south of the Shillong Plateau, which adjoins the ancient oceanic crust that evolved when India was drifted from East Antarctica (Fig. 5a). The gravity signatures, surface morphology, and crustal structures (Figs. 2, 3, and 4) suggest that the NNE segment of the continental margin was evolved in hypo-extended rift process in association with the magmatic activity, while the E-W continental segment was controlled by the Dauki Fault and may have evolved in a shear rift process, similar to the one identified on southern segment of the ECMI ${ }^{17,2}$.

Considering the signatures of NNE oriented low gravity anomaly strip, magnetic doublet connecting the similar age (about 117 - $118 \mathrm{Ma}$ ) volcanic rocks of the Rajmahal and Sylhet, Seaward Dipping Reflectors, Talwani et al. ${ }^{7}$ proposed the second stage of a continental breakup between the northeast Indian Shield in the vicinity of Rajmahal - Sylhet Line and parts of the Kerguelen Plateau at around $120 \mathrm{Ma}$. At this stage, the Kerguelen hotspot had emplaced the Rajmahal and Sylhet traps on Indian Shield and facilitated another continental breakup between India and East Antarctica (Fig. 5a). The breakup not only splits the continental fragments (Elan Bank and parts of the Kerguelen Plateau) from the Indian Shield, but also transfers the conjugate parts of the oceanic crust accreted during M12n anomaly time - just older to $\mathrm{MO}$ anomaly time to the Antarctic plate ${ }^{16,17,7}$. It is appropriate to mention that the paleo coastline in the northeast of India runs very close to the locations of Rajmahal and Sylhet volcanic emplacements, but currently lies far inside from the present-day Bangladesh coastline (Fig. 5a). This implies that there was a presence of passive volcanic continental margin segments east of the Singhbhum craton and south of the Shillong Plateau and an older fragment of the Bay of Bengal having an age of $120 \mathrm{Ma}$ and less right beneath most of the Bangladesh territory. Both the E-W and N-S crustal models demonstrate the presence of thick continental crust adjoining the old oceanic crust of about 8-9 km thick (Figs. 3a and b). The basement rocks recovered in Maddhapara area of northwest Bangladesh (Fig. 1) show the presence of Paleoproterozoic tonalitic and granodioritic rocks having a magmatic age of $1722 \pm 6 \mathrm{Ma}^{58}$. It is further found that the buried rocks in this area are separate and discrete micro-continental fragments ${ }^{58}$, which were emplaced when the Gondwana supercontinent was located in high latitudes of the southern hemisphere.

As the expansion of the northeast Indian Ocean floor continued, the continental collision has occurred between India and Eurasia in the Early Tertiary period ${ }^{22}$ in the north, while in the Indian Ocean, the divergent plate boundary (Wharton spreading ridge) becomes extinct leading to the unification of Indian and Australian plates as a single Indo-Australian lithospheric plate ${ }^{59,21}$. At around Oligocene - Miocene time ( $23 \mathrm{Ma}$ ), the continued process led to the rapid development of the Himalayan mountain range, resulting in origination of Ganges and Brahmaputra river systems for carrying huge deposits of sediments to the Bengal Basin and further to the Bay of Bengal for forming the delta and fan systems ${ }^{23,60}$. Even during the Oligocene - Miocene time, the present-day onshore Bengal Basin was under the Bay of Bengal waters, consequently, the Continent-Ocean Boundary paralleling the East Coast of India up to Mahanadi Basin follows the edges of Singhbhum craton, and Rajmahal - Sylhet Line (Fig. $5 \mathrm{~b}$ ). This implies that the present onshore Bengal Basin was once bordered by the segments of volcanic passive margin on west and sheared margin on north. As sediment deposition continued from Miocene through 
Holocene, the oldest oceanic lithosphere adjoining the continental craton, and volcanic emplacements (Fig. 5b) was buried under the clastic sediments derived from the Himalayas. The deposition process led to prograde the coastline oceanward to the present location, which eventually bury the west and north continental margin segments (Fig. 5b) and old fragment of the Bay of Bengal lithosphere, thereby forming a new margin segment completely built with the sedimentary rocks. The studies of eastern Himalaya drainage patterns and Ganges-Brahmaputra Delta evolution since the Oligocene allowed Betka et al. ${ }^{6}$ to map the location of drifted shoreline through time towards the ocean. Thus, the present-day Bangladesh margin is a unique feature exclusively formed by the progradation of huge sediment deposits over the oceanic crust of the proto-Bay of Bengal and remains an exceptional margin from the ones formed by the processes of continental rifting and breakup.

The near N-S trends of gravity anomaly signatures over the onshore Bengal Basin (Fig. 2) and gravityanomaly derived crustal structures (Figs. 3a, 3b, and 4) clearly show the presence of approximately 200 $\mathrm{km}$ long folded oceanic crust and overlying sedimentary layers. The shortening of this oceanic crust is possibly driven by the resultant processes of ocean-continent collision at the Indo-Burman subduction zone, tectonics offered by the Burmese platelet, convergence across the Dauki Fault, etc. A few questions like plate convergence and shear motions along some of the faults existing in the regions of Bangladesh, northeast India, and Myanmar are still unclear. Analysis of the Harvard CMT data and GPS measurements from the Burmese Arc region led Rao and Kumar ${ }^{61}$ and Gahalaut et al. ${ }^{62}$ to point a possible cessation of eastward subduction, while, Steckler et al. ${ }^{29}$, Mallick et al. ${ }^{63}$ and Fan et al. ${ }^{64}$ opine that subduction process is still active at Indo-Burman plate boundary. However, there is a commonly accepted view among the researchers that the Indian plate subducts with a significant component of strike-slip motion along the edge of Burmese platelet, in addition, some of the fault/ thrust zones within Bangladesh and Burmese platelet are accommodating the east-west convergence. The process of excessive sedimentation in the Ganges-Brahmaputra Delta region prompted Mallick et al. ${ }^{47}$ to believe that the process led to collapsing the Sylhet Trough/ Surma Basin into the mantle, thereby affecting the westward propagation of the Indo-Burman Wedge since the Miocene. Previous studies on subduction process of the Indian lithosphere beneath Burma also suggested a westward trench migration ${ }^{65,45,66}$. Using the Block Model studies Mallick et al. ${ }^{63}$ posited that there is an accumulation of E-W compressional strain within the outer wedge of the deformational front (Fig. 1). The tectonic processes of an eastward moment of the Indian plate, westward propagation of the Indo-Burman Wedge, and convergence across the Dauki Fault together may have applied east-west compression to the oceanic lithosphere lying beneath Bangladesh (Figs. 2 and 4), resulting in formation of long-wavelength lithospheric folding.

\section{Summary And Conclusions}

Bouguer gravity anomaly data of Bangladesh adjoined Indian continental shield, Burmese Arc, and freeair gravity anomaly data of the northern Bay of Bengal are assimilated for generation of a combined map for understanding the gravity responses of various geological features evolved by the processes of Plate 
Tectonics and sediment depositions. The gravity map is the first of its kind covering the land and sea domains in a complex region of the northeast Indian subcontinent. Two gravity anomaly transects running along $23.4^{\circ} \mathrm{N}$ latitude and $91^{\circ} \mathrm{E}$ longitude are modeled for determining the crustal structures and associated tectonics that led to the formation of prominent gravity signatures. Important observations are as follows.

1. The gravity anomaly map depicts a prominent $\mathrm{E}-\mathrm{W}$ elongated positive gravity anomaly over an elevated Shillong Plateau, E-W oriented bulged negative gravity anomaly reaching over the Sylhet Trough, N-S trending gravity anomaly dipping with two different gradients in W-E direction over the Indo-Burman subduction zone, and Burmese Arc, three segments of narrow low gravity anomaly strip along NNE, NE and E-W directions over the region of termination of Indian continental rocks and nearly N-S oriented alternate bands of about $200 \mathrm{~km}$ wide positive and negative anomalies in the Bangladesh region.

2. The $2 \mathrm{D}$ gravity crustal models reveal the presence of paleo-continental margin segments on eastern edge of the Singhbhum craton and south of the Shillong Plateau, approximately $200 \mathrm{~km}$ wide folded oceanic crust beneath Bangladesh, and low gradient subducting Indian plate beneath the Burmese platelet.

3. The passive continental margin segments were evolved after breakup occurred along the edge of the Singhbhum craton and Rajmahal-Sylhet Line for detaching the continental fragments - Elan Bank and southern parts of the Kerguelen Plateau - at about $120 \mathrm{Ma}$. Then the margin segments continue to remain in marine conditions at least until the Oligocene-Miocene time ( 23 Ma). Consequently, huge sediments brought by Ganges and Brahmaputra river systems were deposited on the margin and over an older fragment of the Bay of Bengal lithosphere for the formation of a major delta system leading to its progradation towards the ocean and creation of Bangladesh land. Thus, in the geologic past, a paleo coastline was persisted in the northeast of India close to the locations of Rajmahal and Sylhet volcanic emplacements. This implies that there was a presence of passive volcanic continental margin segments east of the Singhbhum craton and south of the Shillong Plateau and an older fragment of the Bay of Bengal having an age of $120 \mathrm{Ma}$ to younger right beneath most of the Bangladesh territory.

4. The oceanic crust beneath Bangladesh was folded with approximately $200 \mathrm{~km}$ wavelength as the compressive stress regime is locally operative. The shortening of this oceanic crust is possibly driven by the resultant processes of ocean-continent collision at the Indo-Burman subduction zone, tectonics offered by the Burmese platelet, convergence across the Dauki Fault, etc.

\section{Declarations}

\section{Acknowledgments}

The present work is carried out under the project "Nature and Evolution of Lithosphere beneath the offshore Bengal Basin, Bay of Bengal" funded by the DST-SERB, New Delhi (CRG/2019/003607). AR and 
$\mathrm{MI}$ are thankful to DST-SERB, New Delhi for awarding the JRF and INSPIRE Faculty positions, respectively.

\section{Author contributions}

K.S.K. has conceived the idea of collation of land-sea gravity data of the Bengal Basins, carried interpretations, and wrote the manuscript. A.R. has prepared the digital gravity database for the preparation of a map, carried crustal structure and plate reconstruction models, and participated in interpretations. M.I. is involved in the work plan, contributed to the preparation of gravity database, and was involved in interpretation, in some figures preparation, and finalization of the manuscript.

\section{References}

1. Krishna, K.S., Ismaiel, M., Srinivas, K., Gopala Rao, D., Mishra, J. \& Saha, D. Sediment pathways and emergence of Himalayan source material to the Bay of Bengal. Curr. Sci. 118, 363-372 (2016).

2. Ismaiel M, Krishna K S, Srinivas K, Mishra J. \& Saha, D. Crustal architecture and Moho topography beneath the eastern Indian and Bangladesh margins - new insights on rift evolution and the continent-ocean boundary. J. Geol. Soc. London 176, 553-573 (2019).

3. Krishna, K.S., Ismaiel, M., Srinivas, K. \& Saha, D. Post-breakup Deformations in the Bay of Bengal Response of Crustal strata to the Sediment load. J. Earth Sys. Sci. 129159 (2020).

4. Alam, M., Alam, M.M., Curray, J.R., Chowdhury, M.L.R. \& Gani M.R. An overview of the sedimentary geology of the Bengal Basin in relation to the regional tectonic framework and basin-fill history. Sediment. Geol. 155, 179-208 (2003).

5. Mallick, R., Bürgmann, R., Johnson, K. \& Hubbard, J. A unified framework for earthquake sequences and the growth of geological structure in fold-thrust belts. J. Geophys. Res. - Solid Earth 126, e2021JB022045 (2021).

6. Betka, P. M., Thomson, S. N., Sincavage, R., Zoramthara, C., Lalremruatfela, C., Lang, K. A., et al. Provenance shifts during Neogene Brahmaputra delta progradation tied to coupled climate and tectonic change in the eastern Himalaya. Geochemistry, Geophysics, Geosystems 22, e2021GC010026 (2021).

7. Talwani, M., Desa, M.A., Ismaiel, M. \& and Krishna K.S. The Tectonic origin of the Bay of Bengal and Bangladesh. J. Geophys. Res. - Solid Earth 121, 4836-4851 (2016).

8. Sibuet, J.-C., Klingelhoefer, F., Huang, Y.-P., Yeh, Y.-C., Rangin, C., Lee, C.-S. \& Hsu, S.-K. Thinned continental crust intruded by volcanics beneath the northern Bay of Bengal. Mar. Petrol. Geology 77, 471-486 (2016).

9. Curray, J.R. Possible greenschist metamorphism at the base of a 22-km sedimentary section, Bay of Bengal. Geology 19, 1097-1100 (1991).

10. Singh, A., Bhushan, K. et al. Crustal structure and tectonics of Bangladesh: New constraints from inversion of receiver functions. Tectonophysics 680, 99-112 (2016). 
11. Mitra, S., Priestley, K.F., Borah, K. \& Gaur, V.K. Crustal structure and evolution of the Eastern Himalayan Plate boundary system, Northeast India. J. Geophys. Res. - Solid Earth 123, 621-640 (2018).

12. Acharyya, S.K. Collisional emplacement history of the Naga-Andaman ophiolites and the position of the eastern Indian suture. Journal of Asian Earth Sciences 29, 229-242 (2007).

13. Steckler, M.S., Akhter, S.H. \& Seeber, L. Collision of the Ganges-Brahmaputra Delta with the Burma Arc: Implications for earthquake hazard. Earth Planet. Sci. Lett. 273, 367-378 (2008).

14. Socquet, A., Vigny, C., Chamot-Rooke, N., Simons, W., Rangin, C. \& Ambrosius, B. India and Sunda plates motion and deformation along their boundary in Myanmar determined by GPS. J. Geophy. Res. - Solid Earth 111, 1-11 (2006).

15. Vernant, P., Bilham, R., Szeliga, W., Drupka, D., Kalita, S., Bhattacharyya, A.K., Gaur, V.K., Pelgay, P., Cattin, R. \& Berthet, T. Clockwise rotation of the Brahmaputra valley relative to India: tectonic convergence in the eastern Himalaya, Naga hills, and Shillong plateau. J. Geophys. Res. - Solid Earth $119,6558-6571$ (2014).

16. Gaina, C., Müller, R.D., Brown, B., Ishihara, T. \& Ivanov, S. Breakup and early seafloor spreading between India and Antarctica. Geophys. J. Int. 170, 151-169 (2007).

17. Krishna, K.S., Michael, L., Bhattacharyya, R. \& Majumdar, T.J. Geoid and gravity anomaly data of conjugate regions of Bay of Bengal and Enderby Basin: New constraints on breakup and early spreading history between India and Antarctica. J. Geophy. Res. - Solid Earth 114, B03102 (2009).

18. Curray, J.R. \& Munasinghe, T. Origin of the Rajmohal Traps and the $85^{\circ} \mathrm{E}$ Ridge: Preliminary reconstructions of the trace of the Crozet hotspot. Geology 19, 1237-1240 (1991).

19. Krishna, K.S. Structure and evolution of the Afanasy-Nikitin seamount, buried hills and $85^{\circ} \mathrm{E}$ Ridge in the north-eastern Indian Ocean. Earth Planet. Sci. Lett. 209, 379-394 (2003).

20. Ismaiel, M., Krishna, K.S., Srinivas, K., Mishra, J. \& Saha, D. Internal structure of the $85^{\circ} \mathrm{E}$ ridge, Bay of Bengal: Evidence for multiphase volcanism. Mar. Petro. Geol. 80, 254-264 (2017).

21. Krishna, K. S., Abraham, H. Sager, W.W., Pringle, M.S., Frey, F., Gopala Rao, D. \& Levchenko, O.V. Tectonics of the Ninetyeast Ridge derived from spreading records in adjacent oceanic basins and age constraints of the ridge. J. Geophy. Res. - Solid Earth 117, B04101 (2012).

22. Bouilhol, P., Jagoutz, O., Hanchar, J.M. \& Dudas, F.O. Dating the India - Eurasia collision through arc magmatic records. Earth and Planet. Sci. Lett. 366, 163-175 (2013).

23. Curray, J.R. \& Moore, D.G. Growth of the Bengal deep-sea fan and denudation in the Himalayas. Geol. Soc. America Bull 82, 563-572 (1971).

24. Gopala Rao, D., Krishna, K.S. \& Sar, D. Crustal evolution and sedimentation history of the Bay of Bengal since the Cretaceous. J. Geophys. Res. - Solid Earth 102, 17,747-17,768 (1997).

25. Brune, J.N., Curray, J., Dorman, L. \& Raitt, R. A proposed super-thick sedimentary basin, Bay of Bengal. Geophy. Res. Lett. 19, 565-568 (1992). 
26. Curray, J.R. Sediment volume and mass beneath the Bay of Bengal. Earth and Planet. Sci. Lett. 125, 371-383 (1994).

27. Radhakrishna, M., Subrahmanyam, C. \& Damodharan, T. Thin Oceanic crust below Bay of Bengal inferred from 3-D gravity interpretation. Tectonophysics 493, 93-105 (2010).

28. Islam, M.S., Shinjo, R. \& Kayal, J.R. The tectonic stress field and deformation pattern of northeast India, the Bengal basin and the Indo-Burma Ranges: a numerical approach. J. Asian Earth Sci. 40, 121-131 (2011).

29. Steckler, M.S., Mondal, D.R., Akhter, S.H., Seeber, L., Feng, L., Gale, J., Hill, E. M. \& Howe, M. Locked and loading megathrust linked to active subduction beneath the Indo-Burman Ranges. Nature Geoscience 9, 615-618 (2016).

30. Steckler, M.S., Oryan, B., Wilson, C.A., Grall, C., Nooner, S.L., Mondal, D.R., Akhter, S.H., DeWolf, S. \& Goodbred, S.L. Synthesis of the distribution of subsidence of the lower Ganges-Brahmaputra Delta, Bangladesh. Earth-Sci. Reviews 224, 103887 (2022).

31. Rangin, C. Active and recent tectonics of the Burma Platelet in Myanmar. Geol. Soc. London Memoirs 48, 53-64 (2017).

32. Ni, J.F., Speziale, M.G., Bevis, M., Holt, W.E., Wallace, T.C. \& Seager, W.R. Accretionary tectonics of Burma and the three dimensional geometry of the Burma subduction. Geology 17, 68-71 (1989).

33. Rahman, M.A., Mannan, M.A., Blank, H.R., Kleinkopf, M.D. \& Kucks, R.P. Bouguer gravity anomaly map of Bangladesh. Scale 1:1000000. Geol. Surv. Bangladesh, Dhaka (1990).

34. Gravity anomaly map of India. Geological Survey of India, Hyderabad and National Geophysical Research Institute, Hyderabad, India, Maps on 1:2 million scale, pp. 1-3 (2006).

35. Singh, A.P., Kumar, N. \& Singh, B. Magmatic underplating beneath the Rajmahal Traps: Gravity signature and derived 3-D configuration. Proc. Indian Acad. Sci. (Earth Planet. Sci.) <bverticalalign:super;>113</bvertical-align:super;>, 759-769 (2004).

36. Lakra, M.N., Nabakumar, Kh., Saha, D., Hussain, A. \& Prakash, K. Integrated study of gravity and seismic data of Bengal Basin. 10th Biennial International Conference \& Exposition Kochi 2013, P038 (2013).

37. Majumdar, T.J. Crustal depth estimation over the Indian lithospheric plate using satellite geoid and a gravimetric-isostatic model. Curr. Sci. 117, 502-506 (2019).

38. Sandwell, D.T., Müller, R.D., Smith, W.H.F., Garcia, E. \& Francis, R. New global marine gravity model from CryoSat-2 and Jason-1 reveals buried tectonic structure. Science 346, 65-67 (2014).

39. Lohmann, H.H. On the tectonics of Bangladesh, Bull. Swiss Assoc. Petrol. Geol. Eng. 62, 29-48 (1995).

40. Frielingsdorf, J., Islam, S.A., Block, M., Rahman, M.M. \& Rabbani, M.G. Tectonic subsidence modeling and Gondwana source rock hydrocarbon potential, northwest Bangladesh modeling of Kuchma, Singra and Hazipur wells. Mar. Pet. Geol. 25, 553-564 (2008). 
41. Rahman, M.A., Blank, H.R., Kleinkopf, M.D. \& Kucks, R.P. Aeromagnetic anomaly map of Bangladesh: Dhaka. Geol. Surv. Bangladesh Publication, scale1:1,000,000 (1990).

42. USGS - Bangladesh Gas Assessment Team. U.S. Geological Survey-PetroBangla Cooperative Assessment of Undiscovered Natural Gas Resources of Bangladesh, Petroleum Systems and Related Geologic Studies in Region 8, South Asia. Edited by C.J. Wandrey, pp 1-124, available online at: http://geology.cr.usgs.gov/pub/bulletins/b2208-a/ (2001).

43. Mitra, S., Bhattacharya, S.N. \& Nath, S.K. Crustal structure of the western Bengal Basin from joint analysis of teleseismic receiver functions and Rayleigh-wave dispersion. Bull. Seismological Soc. America 98, 2715-2723 (2008).

44. Bora, D.K., Singh, A.P., Borah, K., Anand, A., Biswas, R. \& Mishra, O.P. Crustal Structure Beneath the Indo-Burma Ranges from the Teleseismic Receiver Function and Its Implications for Dehydration of the Subducting Indian Slab. Pure Appl. Geophys. 179, 197-216 (2022).

45. Li, C., van der Hilst, R.D., Meltzer, A.S. \& Engdahl, E.R. Subduction of the Indian lithosphere beneath the Tibetan Plateau and Burma. Earth Planet. Sci. Lett. 274, 157-168 (2008).

46. Bilham, R. \& England, P. Plateau "pop-up" in the great 1897 Assam earthquake. Nature 410, 806-809 (2001).

47. Mallick, R., Hubbard, J.A., Lindsey, E.O., Bradley, K.E., Moore, J.D.P., Ahsan, A., Khorshed Alam, A.K.M. \& Hill, E.M. Subduction initiation and the rise of the Shillong Plateau. Earth Planet. Sci. Lett. 543, 116351 (2020).

48. Biswas, S. \& Grasemann, B. Structural modelling of the subsurface geology of the Sylhet Trough, Bengal Basin. Bangladesh Geoscience Journal 11, 19-33 (2005).

49. Nafe, J.E. \& Drake, C.L. Variations with depth in shallow and deep water marine sediments of porosity, density and the velocity of compressional and shear waves. Geophysics 22, 523-552 (1957).

50. Ludwig, W.J., Nafe, J.E. \& Drake, C.L. Seismic refraction. In: Maxwell, A.E. (ed.) The Sea, Wiley, New York 4, 53-84 (1970).

51. White, R.S., McKenzie, D. \& O’Nions, R.K. Oceanic crustal thickness from seismic measurements and rare earth element inversions. J. Geophys. Res. - Solid Earth 97, 19683-119715, (1992).

52. Christensen, N.I. \& Mooney, W.D. Seismic velocity structure and composition of the continental crust: a global view. J. Geophy. Res. - Solid Earth 100, 9761-9788 (1995).

53. Zhang, G., He, Y., Ai, Y., Jiang, M., Mon, C.T., Hou, G., Thant, M. \& Sein, K. Indian continental lithosphere and related volcanism beneath Myanmar: Constraints from local earthquake tomography. Earth Planet. Sci. Lett. 567, 116987 (2021).

54. Nayak, G.K., Rao, V.K., Rambabu, H.V. \& Kayal, J.R. Pop-up tectonics of the Shillong Plateau in the great 1897 earthquake (Ms 8.7): insights from the gravity in conjunction with the recent seismological results. Tectonics 27, 1-8 (2008).

55. Priestley, K., Ho, T. \& Mitra, S. The crustal structure of the Himalaya: a synthesis. Geol. Soc. London, Spec. Publ. 483, 483-516 (2019). 
56. Dragoi-Stavar, D. \& Hall, S. Gravity modeling of the ocean-continent transition along the South Atlantic margins. J. Geophys. Res. - Solid Earth 114, B09401 (2009).

57. Tasarova, Z.A. Towards understanding the lithospheric structure of the southern Chilean subduction zone $\left(36^{\circ} \mathrm{S}-42^{\circ} \mathrm{S}\right)$ and its role in the gravity field. Geophys. J. Int. 170, 995-1014 (2007).

58. Ameen, S.M.M., Wilde, S.A., Kabir, Md.Z., Akon, E., Chowdhury, K.R. \& Khan, Md.S.H. Paleoproterozoic granitoids in the basement of Bangladesh: A piece of the

59. Indian shield or an exotic fragment of the Gondwana jigsaw? Gondwana Res. 12, 380-387 (2007).

60. Liu, C.S., Curray, J.R. \& McDonald, J.M. New constraints on the tectonic evolution of the eastern Indian Ocean. Earth Planet. Sci. Lett. 65, 331-342 (1983).

61. Curray, J.R., Emmel, F.J. \& Moore, D.G. The Bengal Fan: geometry, stratigraphy, history and processes. Mar. Petrol. Geol. 19, 1191-1223 (2003).

62. Rao, N.P. \& Kumar M.R. Evidences for cessation of Indian plate subduction in the Burmese arc region. Geophys. Res. Lett. 26, 3149-3152 (1999).

63. Gahalaut, V. K., Kundu, B., Laishram, S. S., Catherine, J., Kumar, A., Singh, M. D., et al. Aseismic plate boundary in the Indo-Burmese wedge, northwest Sunda Arc. Geology 41, 235-238 (2013).

64. Mallick, R., Lindsey, E.O., Feng, L., Hubbard, J., Banerjee, P. \& Hill, E.M. Active convergence of the IndiaBurma-Sunda plates revealed by a new continuous GPS network. J. Geophys. Res. - Solid Earth 124, 3155-3171 (2019).

65. Fan, E., He, Y., Ai, Y., Gao, S.S., Liu, K.H., Jiang, M., et al. Seismic anisotropy and mantle flow constrained by shear wave splitting in central Myanmar. J. Geophy. Res. - Solid Earth 126, e2021JB022144, (2021)

66. Rao, N.P. \& Kalpna. Deformation of the subducted Indian lithospheric slab in the Burmese arc. Geophy. Res. Lett. 32, L05301 (2005).

67. Lee, H.-Y., Chung, S.-L. \& Yang, H.-M. Late Cenozoic volcanism in central Myanmar: Geochemical characteristics and geodynamic significance. Lithos $245,174-190$ (2016).

68. Matthews, K.J., Maloney, K.T., Zahirovic, S., Williams, S.E., Seton, M. \& Müller, R.D. Global plate boundary evolution and kinematics since the late Paleozoic. Global and Planet. Change 146, 226250 (2016).

\section{Figures}




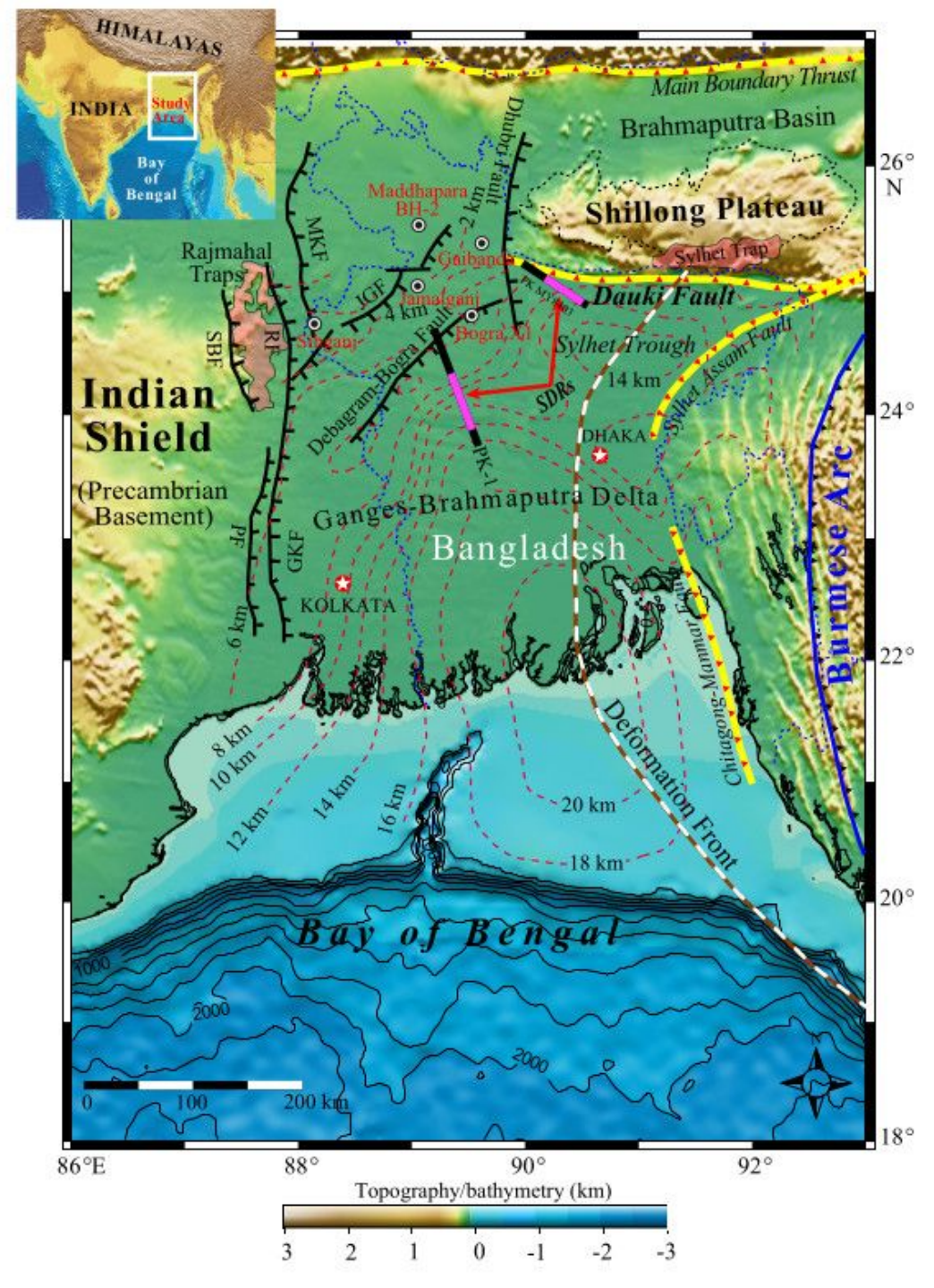

\section{Figure 1}

Morphological map of the eastern Indian Shield, Bangladesh, Burmese Arc, and north Bay of Bengal showing important geological features such as Shillong Plateau, Burmese Arc, Brahmaputra Basin, Sylhet Trough, Deformational Front, Ganges-Brahmaputra Delta, etc. Rajmahal and Sylhet traps are shown as zones with faded red colour. The topographic details are considered from database of Sandwell et al. ${ }^{38}$. Several of the fault lines are also shown. PF = Pingla Fault, SBF = Sainthia Bahmani Fault, GKF = 
Garhmoyna-Khandaghosh Fault, RF = Rajmahal Fault, MKF = Malda-Kishanganj Fault, JGF = JangipurGaibandha Fault. Bathymetry contours with 200 m interval are presented in north Bay of Bengal. Reddashed contours indicate the sediment thickness in both onshore and offshore regions of the Bengal Basin $^{42}$. PK-1 and PK MY 8403 seismic reflection profiles reveal the presence of SDRs ${ }^{39,40}$. Solid dots with open circles indicate the locations of drill holes for sample collection ${ }^{58}$. The inset map shows the regional morphology of the Indian subcontinent, Himalayas and adjacent seas. The rectangular box shows the location of the study area. 


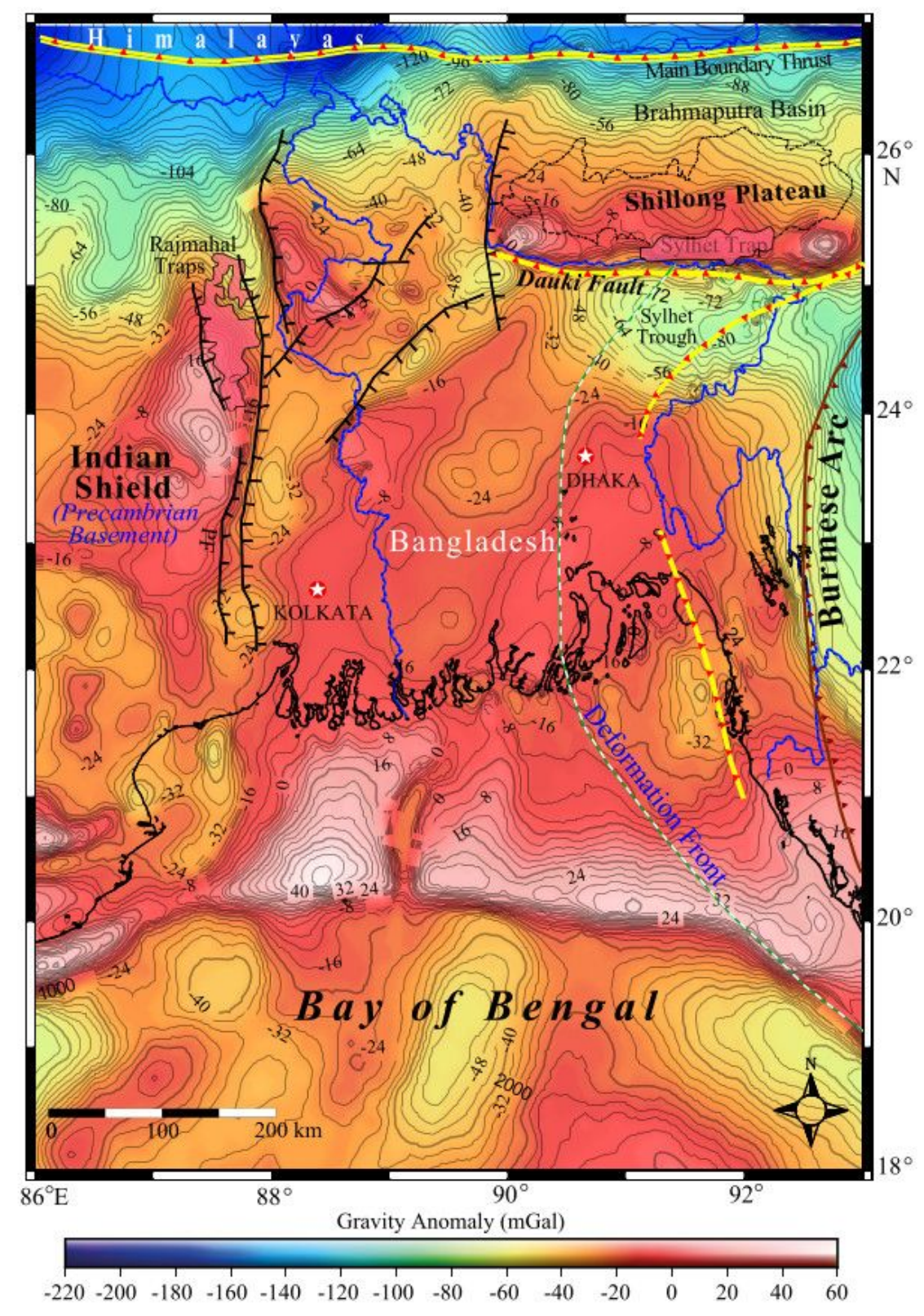

\section{Figure 2}

Integrated gravity anomaly map of the onshore regions consist of Indian Shield, Bengal Basin, Burmese Arc, etc. (Bouguer gravity anomaly) and northern Bay of Bengal (free-air gravity anomaly). The contour interval is $4 \mathrm{mGal}$. The details of geological features, traps, and fault lines are as mentioned in Fig. 1. 

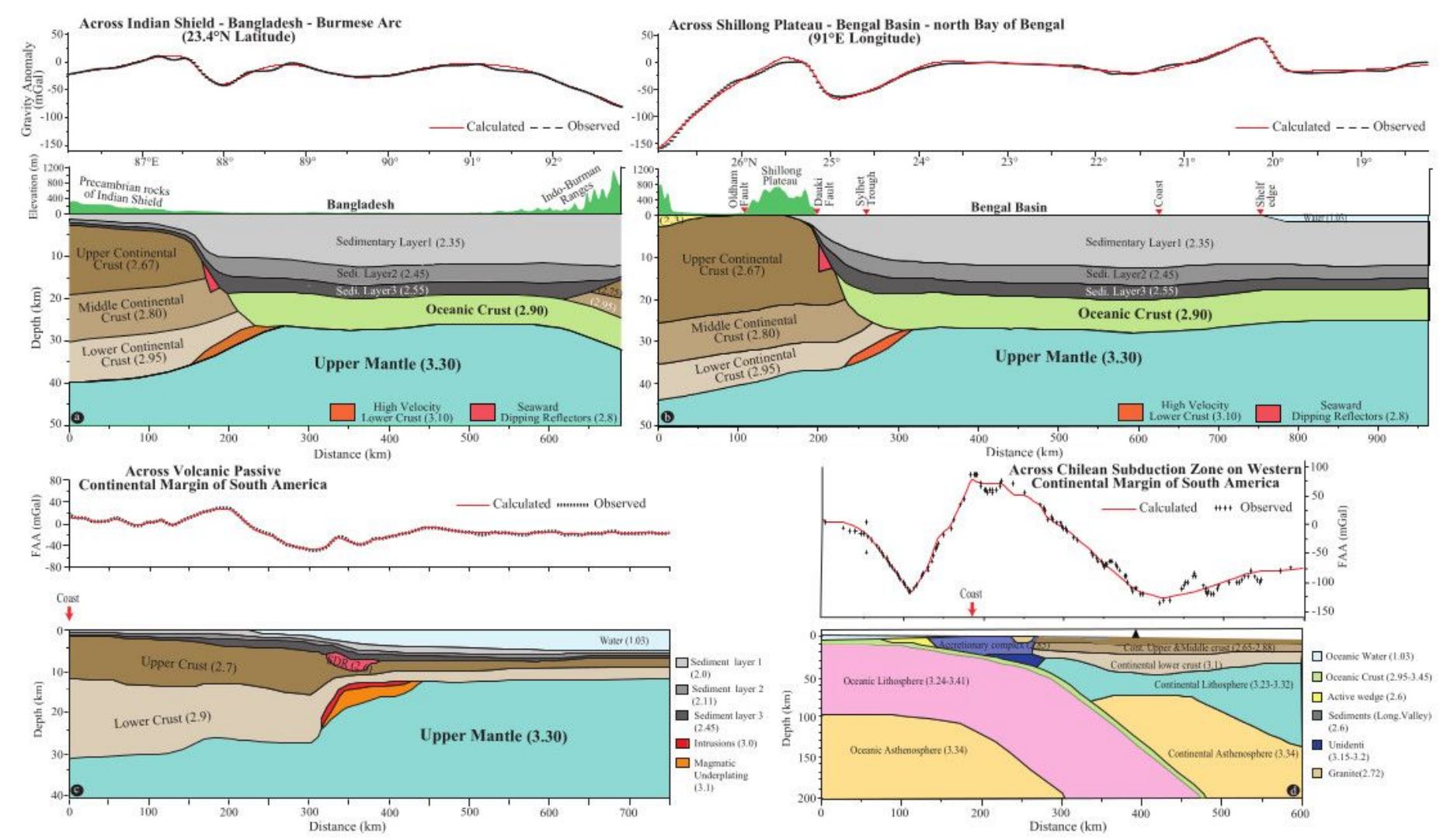

\section{Figure 3}

Crustal models across onshore and offshore Bengal Basins derived from gravity data. The surface topographies are shown in the middle panels. Density values with $\mathrm{gm} / \mathrm{cc}$ are indicated within the layers. The upper panel shows the observed and calculated gravity anomaly data along transects. a) E-W crustal model along $23.4^{\circ} \mathrm{N}$ latitude and b) $\mathrm{N}-\mathrm{S}$ crustal model along $91^{\circ} \mathrm{E}$ longitude. These two models are compared with the crustal models, c) across the volcanic passive continental margin of South America ${ }^{56}$, and d) across the Chilean subduction zone on the western margin of South America ${ }^{57}$.

\section{Figure 4}

Combined perspective view of contour map of gravity anomaly data of the study area and crustal models together with topographies along E-W and N-S transects. The white dashed lines on contour map are transects used for determining crustal models. A white stippled line marks the location of the trench axis 
of the Indo-Burman subduction zone. The yellow stippled line indicates the location of Continent-Ocean Boundary (COB) separating the Precambrian rocks of the Indian Shield from the oceanic crust of protoBay of Bengal.
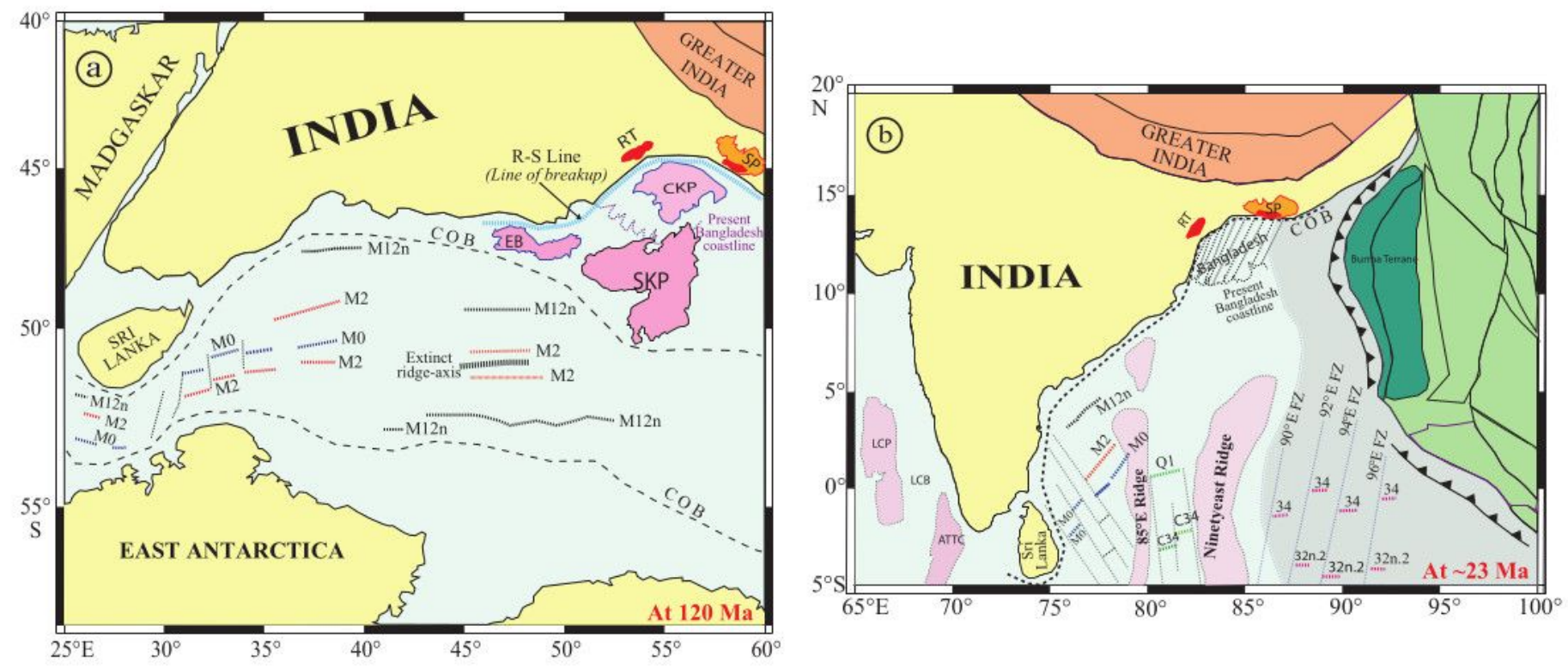

\section{Figure 5}

Plate reconstruction models for the ages 120 and $23 \mathrm{Ma}$ are prepared using Gplates software and pole rotation parameters ${ }^{67}$. a) accretion of ocean floor between India - small micro-continental fragments and East Antarctica during the stage of second continental breakup ( 120 Ma). SKP = Southern Kerguelen Plateau, $\mathrm{CKP}=$ Central Kerguelen Plateau, EB = Elan Bank, RT = Rajmahal Traps, SP = Shillong Plateau, and R-S Line $=$ Rajmahal-Sylhet Line. The micro-continental pieces are about to get detached from the Rajmahal-Sylhet Line. b) The position of India and geometries of coastlines and tectonic features for the age $23 \mathrm{Ma}$. The magnetic lineations in the Bay of Bengal and in the region east of the Ninetyeast Ridge are considered from Talwani et al. ${ }^{7}$ and Krishna et al. ${ }^{21}$, respectively. The shaded zone with light-grey color is the oceanic lithosphere that has been subducted during the last $23 \mathrm{Myr}$. The COB line on east coast of India runs parallel to the coastline, while in the northeast region it runs east of the Rajmahal traps and south of the Shillong Plateau. The dotted lines region is the oceanic crust of the proto-Bay of 
Bengal. Subsequently, the region is buried under the sediments supplied by two great Himalayan rivers, leading to the formation of Bengal Delta and creation of Bangladesh land. 